\title{
Consequences of the Adopted Fatal Addictive Duplet
}

\author{
Nikhil Kumar Vanjari ${ }^{1}$, Gajjela Sirichandana ${ }^{2}$, Asra Shaik ${ }^{2}$, Vallala Akhila ${ }^{2}$, \\ Saini Sowmya ${ }^{2}$, Kanaparthi Sushrutha ${ }^{2}$, Akshima Gupta ${ }^{2}$, Gujjula Sandhya ${ }^{2}$, \\ Myakala Soumya ${ }^{2}$
}

${ }^{1}$ Pharm-D, Clinical Assistant Professor, Department of Clinical Pharmacy, Vaageswari College of Pharmacy,
Karimnagar, Telangana.
${ }^{2}$ Pharm-D, Department of Clinical Pharmacy, Vaageswari College of Pharmacy, Karimnagar, Telangana.

Corresponding Author: Gajjela Sirichandana

\begin{abstract}
This review focus on strong association of smoking and alcohol use with a variety of adverse human health effects, most prominently with cancer and cardiovascular diseases and a number of negative outcomes as a risk factor for diseases and health impacts: crime, road incidence and for some, alcohol dependence. To keep track of alcohol consumption and smoking and its consequences and to raise awareness amongst the public and policy-makers, national monitoring systems to be developed. Tobacco smoking is highly prevalent throughout the world and is, perhaps, the greatest modifiable risk factor for increased morbidity and mortality. Physicians, Pharmacists, Nurses and other healthcare providers have substantial opportunities to influence the pattern of smoking and alcohol usage.
\end{abstract}

Keywords: Alcohol, Smoking, Coronary Heart Disease, Hepatotoxicity, Cancer, Atherosclerosis, Cytochrome P450 enzymes, Alcohol-Drug Interactions, Smoking-Drug Interactions, Smoking and Alcohol Cessation.

\section{INTRODUCTION}

The preventable causes of deaths in the United States are smoking and alcohol which are commonly used together ${ }^{1}$. Studies reported that individuals who consume alcohol are three times more likely to smoke compared to non-alcoholics and individuals who smoke are four times more likely to consume alcohol than the non-smokers ${ }^{2,3}$. Tobacco-related complications are higher in persons consume both alcohol and smoking including multiple cancers, lung disease, and cardiovascular disease ${ }^{4}$.More alcoholics die of tobacco-related illness than that of alcohol-related problems ${ }^{5}$.

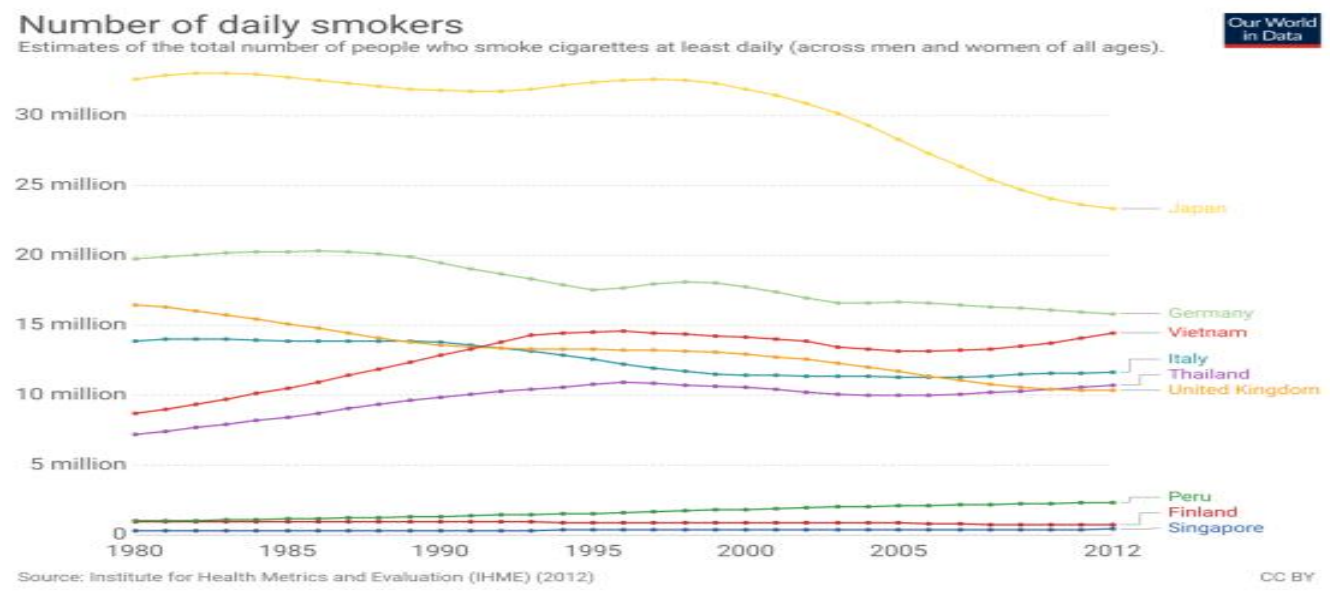

Source:http://ghdx.healthdata.org/record/global-smoking-prevalence-and-cigarette-consumption-1980-2012 


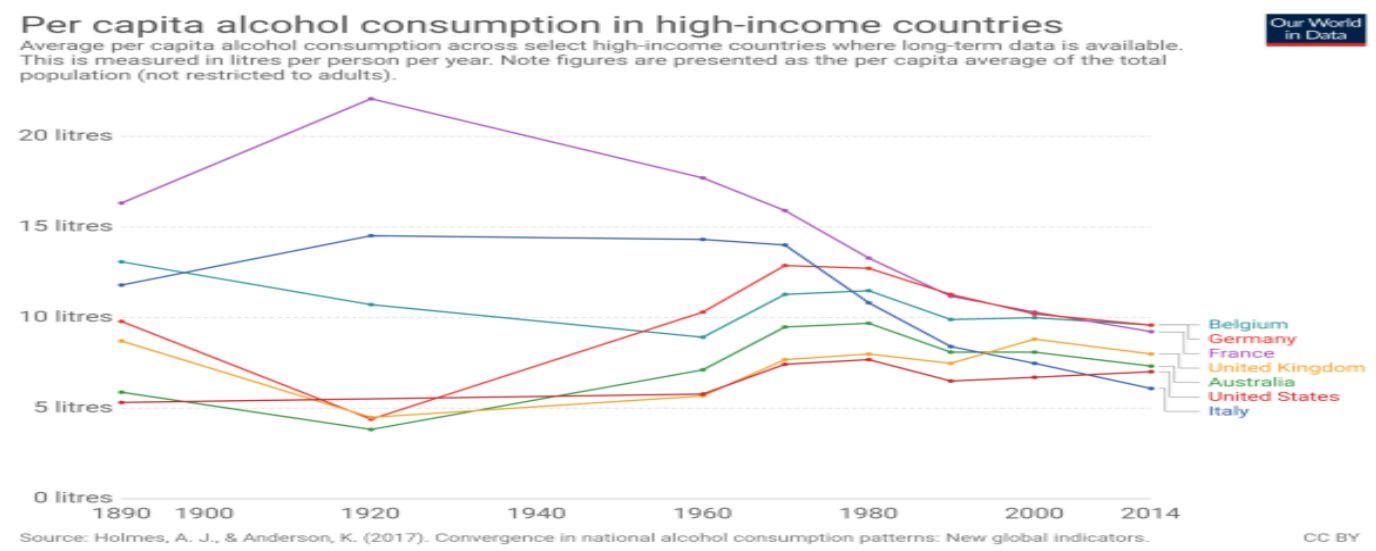

Source: Holmes, A. J., \& Anderson, K. (2017). Convergence in national alcohol consumption patterns: New global indicators. Journal of Wine Economics, 12(2), 117-148.

\section{Effects of alcohol on human physiology 2.1 Effects of alcohol in Central Nervous System}

At neurochemical level, the moderate use of ethanol particularly shows the effect on function of GABA, glutamatergic, serotonergic, dopaminergic, cholinergic, and opioid neuronal systems. Moderate ethanol intake exerts behavioral effects which include actions that the human or animal will identify as reinforcing through either positive (e.g., pleasant, activating) or negative (e.g., anxiolytics, stress reduction) reinforcement mechanism 6 . Different actions of alcohol on the developing organism, including the brain, cause cell death. Necrosis and apoptosis are two general processes of necrobiosis. These processes can be differentiated by completely contrasting patterns of morphological and biochemical changes during cell death.

A major factor which induces apoptosis and necrosis is oxidative stress. Free radicals contain oxygen known as reactive oxygen species (ROS). Usually, antioxidants are the scavenger molecules that are normally found within the cell and control the levels of ROS and other free radicals and eliminate them. Oxidative stress can result if ROS levels exceed the cell's potential to eliminate them, or if the normal antioxidant levels inside the cell are decreased due to a toxic insult such as alcohol. This oxidative stress can result in injury to cellular components, like membranes, DNA and proteins ${ }^{7,8}$.

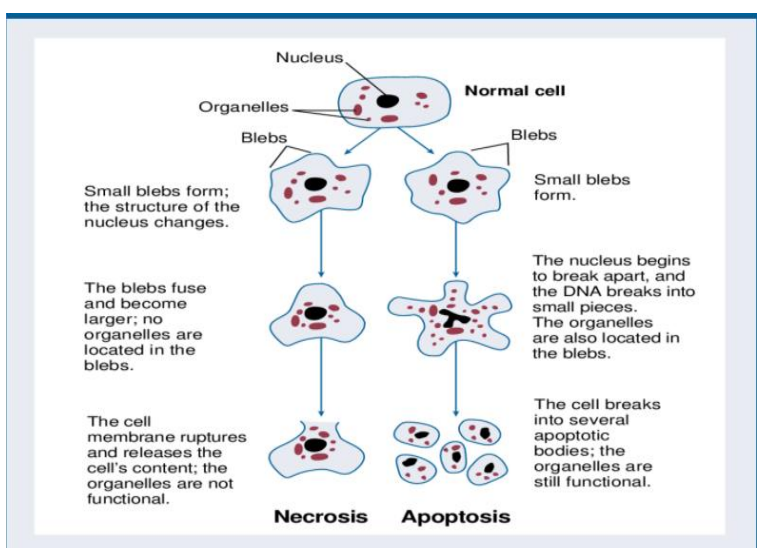

Structural changes of cells undergoing Necrosis or Apoptosis. Source: Nanji, A.A. and Hiller-Sturmhöfel, S. (1997) Apoptosis and Necrosis: Two Types of Cell Death in Alcoholic Liver Disease. Alcohol Health and Research World, 21, 325-330.

\subsection{Effects on Cardiovascular System}

Alcohol is a known risk factor for stroke and coronary heart disease (CHD). Alcohol increases blood pressure, which may lead to hypertension and thus increase the risk of stroke. HDL cholesterol, which is inversely related to $\mathrm{CHD}$ risk, increases with alcohol, and LDL cholesterol, which is positively related to $\mathrm{CHD}$ risk $^{9}$. Cardiac arrhythmias caused by regular heavy drinking or binge drinking can provoke the formation of thrombus and spread existing thrombi from the heart. The maintenance of high blood pressure by heavy drinking can cause cerebral arterial degeneration ${ }^{10}$.

\subsection{Effects on Endocrine System}

The most important of the effects on endocrine system are alcohol-induced 
'pseudo-Cushing's syndrome' and a syndrome of hypothalamic-pituitaryadrenocortical unresponsiveness. Both of these result from long-term overindulgence, and impairment of secretion of testosterone which may occur following comparatively short-term drinking. Evidence indicates that many mechanisms are responsible for mediating the effects of alcohol on endocrine function. In a few instances like inhibition of vasopressin secretion and impairment of steroidogenesis resulting in a decrease in testosterone production rate, alcohol appears to influence directly the release or production of individual hormones ${ }^{11}$.

\subsection{Effect on Pancreas:}

Alcohol and its metabolites turn out changes within the acinar cells, which may promote premature activation of intracellular digestive enzyme, thus predisposing the gland to autodigestive injury. Pancreatic stellate cells (PSCs) are activated directly by alcohol and its metabolites and additionally by cytokines and growth factors which are released in alcohol-induced pancreatic necroinflammation. Activated PSCs are the major cells responsible for causing the fibrosis in alcoholic chronic pancreatitis ${ }^{12}$.

\subsection{Effect on Liver:}

Liver disease in alcoholics is due to malnutrition and also because of ethanol's hepatotoxicity associated to its metabolism by means of alcohol dehydrogenase and cytochrome P450 2E1 (CYP2E1) pathways and the resulting production of toxic acetaldehyde. In addition, alcohol dehydrogenase-mediated metabolism of ethyl alcohol generates nicotinamide adenine dinucleotide (NADH) that promotes steatosis by stimulating the synthesis of fatty acids and opposing their oxidation. Steatosis is also promoted by high dietary lipids and may be attenuated by their replacement with medium-chain triglycerides. Elevated NADH also increases lactate, through reduction of pyruvate, which stimulates synthesis of collagen in myofibroblasts ${ }^{13}$.

It is of note that although cirrhosis is usually the primary pathophysiological process that results in development of hepatocellular carcinoma, ALD may progress into liver cancer without necessarily going through cirrhosis ${ }^{14}$.

\subsection{Effectiveness of Alcohol Management}

The evidence shows that although information and education type programs do not reduce alcohol related harm, they have an important role in providing information, and in increasing attention ${ }^{15}$.Alcoholism is a harmful condition that typically follows the intake of a huge amount of alcohol which can exhibit itself clinically in many ways and leads to metabolic effects along with gastrointestinal, central nervous, endocrine, pulmonary and cardiac effects. The management is aimed by stabilizing the patient's clinical condition by the elimination of alcohol. It is up to both governments and concerned citizens to encourage public health policies that minimize the harm caused by alcohol.

\section{Effects of smoking on human physiology}

15-20 years of life is reduced among one smoker in four and half of them die due to complications caused by smoking, which also contributes to $85 \%$ of lung cancer ${ }^{16}$. It is prominently fatal to respiratory, cardiovascular, reproductive, integumentary, oral cavity, skeletal systems ${ }^{17,18,19}$.

3.1 Integumentary System: injury to epithelial and collagen tissue is caused by decreased perfusion of blood and oxygen to the skin contributing to risky surgeries, poor wound healing ${ }^{17}$.

3.2 Oral Cavity: Smoking promotes tooth decay and infection because of reduced salivary flow which protects teeth. Smokers have recurrent pharyngitis, oral cancer, lessened sensation to taste and smell, stained teeth and plaque, bad breath ${ }^{17}$. 
3.4 Respiratory system: Smoking causes shortness of breath, chronic obstructive pulmonary disease, pneumonia, lung cancer, chronic bronchitis ${ }^{18}$.

\subsection{Reproductive System: Chronic} smoking impairs ovulation, cervical ${ }^{21}$, cancer decreased sperm count and motility and $^{17}$. Maternal smoking is associated with placental abruption, preterm delivery, placenta Previa, low birth weight ${ }^{20}$.

3.6 Heart: Tobacco adversely effects endothelial and smooth muscle cell functions disturbing thrombotic events influencing development of atherosclerosis. Smoking decreases exercise tolerance, increases risk of coronary heart disease blood pressure and tendency to $\operatorname{clot}^{17,18,19}$.

3.7 Cancer: tobacco smoke exposure and smokeless tobacco products are associated with cancers of head, neck, gastrointestinal tract, breast, kidney and leukemia ${ }^{22}$. Polymorphic enzymes of Cytochrome P450, glutathione S-transferase, Nacetyltransferase modulate formation of DNA adducts, induction of mutations and chromosomal damage which causes cancer $^{25-33}$. Smokers have three to seven times higher risk for esophageal squamous cell carcinoma compared to nonsmokers ${ }^{32,33}$.A meta-analysis study reported that 20 to 30 percent of patients suffering from esophageal cancer were addicted to smoking $^{36}$.many studies concluded that incidence of liver cancer is higher among smokers ${ }^{37}$.High alcohol intake, hepatitis B or $\mathrm{C}$ prevent inhibition of tumor growth by DNA adduct formation ${ }^{40}$. Smoking is also a major risk factor for cervical cancer ${ }^{39}$.The incidence of cervical cancer and renal cell carcinoma depends on duration of smoking and number of cigarettes ${ }^{40-42}$

\subsection{Health Benefits of Smoking Cessation}

The considerable health benefits of smoking cessation are reduce the risk of smoking related diseases, slows the progression of current smoking related disease, and improves the life span of an individuals by an average of 10 years ${ }^{16}$. Smoking cessation can bring good results regardless of age and how long he/she smoked and improves the person's heart rate, blood pressure and peripheral circulation within 1day, the content of carbon monoxide within the lungs also reduced by 24 hours and all nicotine has left from the body within 48hours. Lung function is improved after 1to 3 months by $30 \%$ and improve the symptoms like shortness of breath and cough and their frequency is reduced in chronic smoker after 6 months of stopping smoking ${ }^{43,46}$ the risk of lung cancer falls by $50-60 \%$ after 10 years of quitting smoking and risk of heart attack and stroke also reduced after 15years abstinence of smoking ${ }^{17}$.

\subsection{Promoting Smoking Cessation}

Smoking is a common risk factor for majority of individuals suffers with hypertension, diabetes and other heart diseases. In many health care centers smoking status is vital sign along with blood pressure, pulse rate, and temperature recorded by nurses. The presence of treatment may initiate or enhance the quitting ${ }^{16}$. Every discharge protocols of patients suffered with heart attack are taking beta-blockers, aspirin, ACE inhibitors and statins. Adherence to medical therapy also improves the patient condition. Physician plays a important role in promoting smoking cessation by educating the patient about the smoking related problems and medical therapy with the help of other health care professionals ${ }^{16}$. Seventy percent of smokers want to quit, but only 3-7 percent will be successful on their own ${ }^{44}$. Smoking cessation is complex process and it is extremely difficult and may require several strategies and counselling sessions to reach the ultimate goal and to improve the condition. The more effective interventions such as behavioral and pharmacological therapies improve the quit rates only 15 $30 \%$ in smokers $^{44}$. It is hesitant that physicians continue to work with patients on 
an ongoing basis to find cessation manner that work for them. Increasing quit rates up to 1.5 - 2 fold by using nicotine replacement therapies (such as the patch, gum or inhaler) and Bupropion ${ }^{45}$. The quit rates increased 2to 3-fold over placebo by using Varenicline. Behavioral therapy, psycho-social therapy also effective tool in promoting smoking cessation. The effective way of turning tide of tobacco smoking is by friends and support of family members and also Government by making policies, wide restrictions and taxes.

\section{Drug interactions with alcohol and smoking}

Many medications interact with cigarette smoke and alcohol via pharmacokinetic or pharmacodynamics mechanisms. Engaging in both of these social activities can reduce the efficiency of certain drugs or can make drug therapy unpredictable ${ }^{47}$.

\subsection{Smoking Pharmacokinetic interactions}

The chemicals in Cigarette smoke such as polycyclic aromatic hydrocarbons induces the activity of cytochrome $\mathrm{P} 450$ (CYP) $1 \mathrm{~A} 2^{46}$ and also CYP2B6. ${ }^{49}$ The clinically important drugs (such as antidepressants and antipsychotics) are metabolized by these enzymes and chemicals in cigarette smoke also has procarcinogenic activity $^{48,50}$. In heavy smokers (more 20 cigarettes/day) CYP 1A2 activity is high compared to nonsmokers ${ }^{52}$. Nicotine in tobacco not influence the activity of CYP1A2, but activity induced by cigarette smoke. So nicotine replacement therapy does not influence the CYP1A2 activity ${ }^{49}$.

\begin{tabular}{|l|l|}
\hline $\begin{array}{l}\text { Drugs interaction } \\
\text { with smoking }\end{array}$ & Mechanisms \\
\hline Warfarin & $\begin{array}{l}\text { Smoking induces the activity of CYP1A2, Smoking may therefore potentially interact with warfarin by increasing its } \\
\text { clearance and reducing its effect. Because of Warfarin less active R isomer is eliminated to a minor extent by } \\
\text { CYP1A2 }^{53} \text { Consequently, INR should be closely monitored when there is a change in patients smoking status }\end{array}$ \\
\hline $\begin{array}{l}\text { Clopidogrel and } \\
\text { prasugrel }\end{array}$ & $\begin{array}{l}\text { Clopidogrel and prasugrel converted into their active metabolites by CYP isoenzymes (including CYP2C19, 3A4/5, } \\
1 \text { A2, 2B6 and 2C9) these metabolites are bind to the receptors on platelets irreversibly. Cigarette smoke induce the } \\
\text { activity of CYP1A2 results it could increase the antiplatelet efficacy of these thienopyridine drugs }\end{array}$ \\
\hline Caffeine & $\begin{array}{l}\text { Caffeine depends on CYP1A2 for its metabolism. Cigarette smoke enhance the activity of CYP1A2,To achieve the } \\
\text { same plasma caffeine concentration smokers requires 4 times of caffeine in smokers compared to non-smokers }\end{array}$ \\
\hline Heparin & $\begin{array}{l}\text { cigarette smoke activates thrombosis with enhanced heparin binding to antithrombin III, results faster clearance of } \\
\text { heparin }\end{array}$ \\
\hline Antipsychotics & $\begin{array}{l}\text { Heavy smoking may reduce the blood levels of antipsychotic medications by as much as 50 percent, Because of } \\
\text { Cigarette smoke consists of polycyclic hydrocarbons stimulate the hepatic microsomal system, inducing liver } \\
\text { enzymes to increase the metabolism of psychotropic medications }\end{array}$ \\
\hline Insulin & $\begin{array}{l}\text { Smoking cause release of Endogenous substances that antagonize the effects of insulin, and decreases its } \\
\text { absorption }\end{array}$ \\
\hline
\end{tabular}

Pharmacodynamic interactions- Pharmacodynamic drug interactions with tobacco smoke are due to nicotine.

\begin{tabular}{|c|c|}
\hline Benzodiazepines & $\begin{array}{l}\text { Nicotine stimulates the } \mathrm{CNS}^{60} \text { and this might explain the sedation noticed in smokers compared to non-smokers taking } \\
\text { benzodiazepines }\end{array}$ \\
\hline $\begin{array}{l}\text { Oral } \\
\text { contraceptives }\end{array}$ & $\begin{array}{l}\text { Smoking increases the adverse effects with oral contraceptive pills (specifically thromboembolism, ischemic stroke } \\
\text { and myocardial infarction) }{ }^{60}\end{array}$ \\
\hline Corticosteroids & $\begin{array}{l}\text { The efficacy of inhaled corticosteroids may be decreased in asthmatic patients in smokers, }{ }^{60} \text { so these patients might } \\
\text { need higher doses of inhaled corticosteroids for asthma control }{ }^{62} \text { Proposed mechanisms of corticosteroid insensitivity } \\
\text { involve suppression of histone deacetylase expression by smoking, causing inflammatory gene expression and } \\
\text { decrease in glucocorticoid function }{ }^{63} \text { Clearance of corticosteroids from the lungs may be altered by increased mucus } \\
\text { secretion or airway permeability }{ }^{64}\end{array}$ \\
\hline Beta blockers & $\begin{array}{l}\text { Smoking also inhibits nicotine mediated sympathetic activation which reduces the Antihypertensive and heart rate } \\
\text { control effects of several Beta blockers }{ }^{65}\end{array}$ \\
\hline Opioids & $\begin{array}{l}\text { Laboratory based human self-control studies have shown that nicotine and opiates (e.g., heroin, morphine, methadone) } \\
\text { interact to increase total drug abuse. For example, heroin }{ }^{66} \text { or methadone }{ }^{67} \text { administration increases smoking while } \\
\text { methadone also increases the subjective ratings of smoking satisfaction }{ }^{67} \text {. Nicotine and opiates also produce cross- } \\
\text { tolerance }{ }^{68} \text { or cross-sensitization }{ }^{69} \text { such that exposure to one drug alters the response to the other in CPP procedures, } \\
\text { depending on the duration of administration. }\end{array}$ \\
\hline Antihypertensives & $\begin{array}{l}\text { Clinical experiments as well as population studies, both prospective and cross- sectional, have established that } \\
\text { commonly used antihypertensive drugs affect the plasma lipid and lipoprotein profile adversely, potentially increasing } \\
\text { the risk of coronary morbidity }{ }^{70}\end{array}$ \\
\hline
\end{tabular}

\subsection{Alcohol:}


People normally complaints euphoria after drinking alcohol, although it depends on the social setting. However the interaction between many medications and alcohol can lead to a significant increase in risk of illness, injury, or even death ${ }^{71}$

\begin{tabular}{|c|c|}
\hline $\begin{array}{l}\text { Drugs interacts with } \\
\text { alcohol }\end{array}$ & Mechanisms \\
\hline $\begin{array}{lr}\text { Non-Steroidal } & \text { Anti- } \\
\text { Inflammatory } & \text { Drugs } \\
\text { and Statins } & \end{array}$ & $\begin{array}{l}\text { NSAIDS like aspirin, ibuprofen, naproxen, ketoprofen, and nabumetone when taken } \\
\text { with alcohol increase the threat of liver injury or stomach bleeding. The increased metabolism of HMG-CoA } \\
\text { reductase inhibitors like atorvastatin, cerivastatin, lovastatin, pravastatin and simvastatin due to this interaction } \\
\text { increases the risk of liver damage in alcoholics }{ }^{72}\end{array}$ \\
\hline $\begin{array}{l}\text { Disulfiram } \\
\text { Antibiotics }\end{array}$ & $\begin{array}{l}\text { Disulfiram-alcohol interaction is a typical example of the inhibitory metabolic effects caused by a Drug-alcohol } \\
\text { interaction }^{73} \text {. Disulfiram inhibits aldehyde dehydrogenase, thus inhibiting oxidation of acetaldehyde, an oxidation } \\
\text { product of alcohol results in accumulation of acetaldehyde and progress of unpleasant effects characteristic of } \\
\text { disulfiram reaction. Disulfiram like reaction is seen in patients receiving cephalosporin's like cefotetan, } \\
\text { cefamondole, cefmetazole and following consumption of alcohol. Methylthiotetrazole which is an essential } \\
\text { substituent of all the above antibiotics is the main cause of reaction }{ }^{74} \text {. }\end{array}$ \\
\hline Antidepressants & $\begin{array}{l}\text { Alcohol increases the sedative effects of tricyclic antidepressants (TCAs) through pharmacodynamic } \\
\text { interactions. In addition, alcohol can cause pharmacokinetic interactions with TCAs. }\end{array}$ \\
\hline Antihistamines & $\begin{array}{l}\text { Antihistamines may cause drowsiness, sedation, and low blood pressure (i.e., hypotension), especially in elderly } \\
\text { patients. Through pharmacodynamic interactions, alcohol can substantially increases the sedating effects of these } \\
\text { agents and may increase a person's risk of falling or impair his or her ability to drive or operate other } \\
\text { alternatives of machinery }\end{array}$ \\
\hline Benzodiazepines & $\begin{array}{l}\text { Simultaneous consumption of BZDs and average amounts of alcohol can cause synergistic sedative effects, } \\
\text { leading to substantial CNS impairment. It is worth noting that both barbiturates and benzodiazepines can impair } \\
\text { memory, as alcohol. Consequently, the amalgamation of these medications with alcohol would exacerbate this } \\
\text { memory-impairing effect. }\end{array}$ \\
\hline Muscle relaxants & $\begin{array}{l}\text { Several muscle relaxants (e.g., carisoprodol, cyclobenzaprine, and baclofen), if taken with alcohol, may produce } \\
\text { a narcotic-like reaction that is characterized by fatigue, dizziness, agitation, euphoria, and confusion }{ }^{75}\end{array}$ \\
\hline
\end{tabular}

\section{CONCLUSION}

Cigarette and alcohol use share common etiological factors and frequently develop simultaneously. Adolescents are more likely to be involved in health risk habits or delinquency, such as smoking, alcohol consumption, or drug abuse when they are exposed to certain surroundings; it increases pleasure and sociability in the minds of every individual. To reduce the burden of alcohol-related problems, consider average consumption of alcohol and patterns of drinking. To reduce the health burden of alcohol, avoiding the combination of drinking and driving. Worldwide, especially, in developing countries like china, India smoking and alcohol consumption plays important role on lives and its contribution to the overall burden of disease is expected to increase in the future. To keep track of alcohol consumption and smoking and its consequences and to raise awareness amongst the public and policy-makers, national monitoring systems to be developed. Tobacco smoking is highly prevailing throughout the world and is perhaps, the greatest modifiable risk factor for increased morbidity and mortality. Smoking cessation is associated with immediate and long-term health benefits, resulting in improved general health and a reduced risk of smoking-related diseases.

Physicians, Pharmacists, Nurses and other healthcare providers have substantial opportunities to influence the pattern of smoking and alcohol usage. The motivation to attempt cessation of these habits is to be encouraged and it would only be successful with the willingness of the individual. Familiarity with the strategies involved in cessation of smoking, alcohol and practicing the same would be an effective health intervention. A combination of behavioral counseling and pharmacotherapy would reduce the withdrawal syndromes which increases the abstinence rates. From the evidence of the recent literature there are several medications available helping smokers and alcoholics to quit with demonstrated efficacy according to the patient interest and medical history. The warning tags displayed in different occasions and even on the containers of alcohol and tobacco products are mostly futile. Employment of effective public 
health awareness programs, ban of production that practically help out the nation's burden are to be concerned.

\section{Acknowledgement: None}

\section{Conflict of Interest: None}

\section{Source of Funding: None}

\section{REFERENCES}

1. UNODC (2011) World Drug Report. United Nations Publication, sales No. E11.XI.10.

2. Mokdad AH, Marks JS, Stroup DF, Gerberding JL (2004) Actual causes of death in the United States, 2000. Journal of American Medical Association 291: 12381245.

3. Yusuf S, Hawken S, Ounpuu S, Dans T, Avezum A, et al. (2004) Effect of potentially modifiable risk factors associated with myocardial infarction in 52 countries (the INTERHEART study): casecontrol study. Lancet 364: 937-952.

4. Hymal S, Ford L (2003) School Completion and Academic Success: The Impact of Early Social-Emotional Competence. available www.excellence-

earlychildhood.ca/documents/Hymel-

FordANGxp.pdf

5. Nichter M, Carkoglu A, Lloyd-Richardson E (2010) Smoking and drinking among college students: "it's a package deal". Drug Alcohol Depend 106: 16-20.

6. Eckardt MJ, File SE, Gessa GL, Grant KA, Guerri C, Hoffman PL, Kalant H, Koob GF, Li TK, Tabakoff B. Effects of moderate alcohol consumption on the central nervous system. Alcoholism: Clinical and Experimental Research. 1998 Aug;22(5): 998-1040.

7. BREDENSEN, D.E. Keeping neurons alive: The molecular control of apoptosis (Part 1). The Neuroscientist 2:181-190, 1996a.

8. BREDENSEN, D.E. Keeping neurons alive: The molecular control of apoptosis (Part II). The Neuroscientist 2:211-216, $1996 \mathrm{~b}$.

9. Criqui $\mathrm{MH}$. The roles of alcohol in the epidemiology of cardiovascular diseases. ActaMedicaScandinavica. 1987 Jan 12;221(S717):73-85.

10. Hillborn M. Alcohol consumption and stroke: benefits and risks. Alcoholism:
Clinical and Experimental Research. 1998 May;22:352s-8s.

11. Wright J. 6 Endocrine effects of alcohol. Clinics in endocrinology and metabolism. 1978 Jul 1;7(2):351-67.

12. Apte MV, Pirola RC, Wilson JS. Mechanisms of alcoholic pancreatitis. Journal of gastroenterology and hepatology. 2010 Dec;25(12):1816-26.

13. Lieber CS. Alcoholic fatty liver: its pathogenesis and mechanism of progression to inflammation and fibrosis. Alcohol. 2004 Aug 1;34(1):9-19.

14. Altamirano J, Bataller R. Alcoholic liver disease: pathogenesis and new targets for therapy. Nat Rev GastroenterolHepatol 2011; 8: 491-501.

15. Anderson P, Chisholm D, Fuhr DC. Effectiveness and cost-effectiveness of policies and programmes to reduce the harm caused by alcohol. The lancet. 2009 Jun 27;373(9682):2234-46.

16. Young RP, Hopkins RJ, Smith M, Hograth DK. Smoking cessation: the potential role of risk assessment tools as motivational triggers. Postgrad Med J. 2010;86(1011): 26-33.

17. Office of the Surgeon General of the United States. The health consequences of smokingnicotineaddiction;1988.http://profil es.nlm.nih.gov/NN/B/B/Z/D/_/nnbbzd.pdf. Accessed December 3, 2010.

18. Peto R. Smoking and death: the past 40 years and the next 40. BMJ. 1994; 309(6959):937-939.

19. Jemel A, Thun MJ, Ries LA, et al. Annual report to the nation on the status of cancer, 1975-2005, featuring trends in lung cancer, tobacco use, and tobacco control. $J$ Natl Cancer Inst. 2008;100(23):1672-1694.

20. Shiverick KT, Salafia C. Cigarette smoking and pregnancy I: ovarian, uterine, and placental effects. Placenta. 1999;20(4):265272.

21. McCann MF, Irwin DE, Walton LA, Hulka BS, Morton JL, Axelrad CM. Nicotine and cotinine in the cervical mucus of smokers, passive smokers, and nonsmokers. Cancer Epidemiol Biomarkers Prev. 1992;1(2):125129

22. Powell J. Vascular damage from smoking: Disease mechanisms at the arterial wall. Vascular Med 1998;3:21-8. 
23. Hutchinson S. Smoking as a risk factor for endothelial dysfunction. Can J Cardiol 1998;14:20D-2D.

24. Pershagen G, Akerblom G, Axelson O, et al. Residential radon exposure and lung cancer in Sweden. N Eng J Med1994;330:159-64.

25. Zheng W, Deitz AC, Campbell DR, et al. Nacetyltransferase 1 genetic polymorphism, cigarette smoking, well-done meat intake, and breast cancer risk. Cancer Epidemiol Biomarkers Prev 1999;8:233-9.

26. Slattery ML, Potter JD, Samowitz W, Bigler J, Caan B, Leppert M. NAT2, GSTM-1, cigarette smoking and risk of colon cancer.CancerEpidemiol Biomarkers Prev 1998;7:1079-84.

27. Badawi AF, Stern SJ, Lang NP, Kadlubar FF. Cytochrome P-450 and acetyltransferase expression as biomarkers of carcinogenDNA adduct levels and human cancer susceptibility. ProgClinBiol Res1994;395: 109-40.

28. Wu X, Amos CI, Kemp BL, et al. Cytochrome P450 2E1 Dral polymorphisms in lung cancer in minority populations. CancerEpidemiol Biomarkers Prev 1998;7:13-8.

29. Hung HC, Chuang J, Chien YC, et al. Genetic polymorphisms of CYP2E1, GSTM1, and GSTT1; environmental factors and risk of oral cancer. Cancer Epidemiol Biomarkers Prev 1997;6:901-5.

30. Taioli E, Ford J, Trachman, J, Li Y, Demopoulos R, Garte S. Lung cancer risk and CYPIA1 genotype in AfricanAmericans.Carcinogenesis 1998;19:813-7.

31. Dong SX, Ping ZZ, Xiao WZ, et al. Effect of active and passive cigarette smoking on CYP1A2-mediated phenacetin disposition in Chinese subjects. Ther Drug Monit 1998;20:371-5.

32. Soni M, Madurantakan M, Krishnaswamy K. Glutathione S-transferase Mu (GST Mu) deficiency and DNA adducts in lymphocytes of smokers. Toxicology 1998;126:155-62.

33. Nakachi K, Imai K, Hayashi S, Kawajuri K. Polymorphisms of CYP1A1 and gluthathione S-transferase genes associated with susceptibility to lung cancer in relation to cigarette dose in a Japanese population. Cancer Res 1993;53:2994-9.

34. Morita M, Kumashiro R, Kubo N, Nakashima Y, Yoshida R, Yoshinaga K. 2010 Alcohol drinking, cigarette smoking, and the development of squamous cell carcinoma of the esophagus: epidemiology, clinical findings, and prevention. International Journal of Clinical Oncology $15,126-34$.

35. Islami F, Fedirko V, Tramacere I, Bagnardi V, Jenab M, Scotti L. 2011 Alcohol drinking and esophageal squamous cell carcinoma with focus on light-drinkers and never-smokers: a systematic review and meta-analysis. International Journal of Cancer 129, 2473-84.

36. Ferronha I, Bastos A, Lunet N. 2012 Prediagnosis lifestyle exposures and survival of patients with gastric cancer: systematic review and meta-analysis. European Journal of Cancer Prevention 21, 449-52.

37. Lee YC, Cohet C, Yang YC, Stayner L, Hashibe M, Straif K. 2009 Meta-analysis of epidemiologic studies on cigarette smoking and liver cancer. International Journal of Epidemiology 38, 1497-511.

38. Alberg AJ, Hebert JR. 2009 Cigarette smoking and bladder cancer: a new twist in an old saga? J Natl Cancer Inst. 2009 Nov 18;101(22):1525-6. doi: 10.1093/jnci/ djp385.

39. de Vet HC, Sturmans F, Knipschild PG. 1994 The role of cigarette smoking in the etiology of cervical dysplasia. Epidemiology (Cambridge, Mass.) 5, 631-3.

40. Brisson J, Morin C, Fortier M, Roy M, Bouchard C, Leclerc J. 1994 Risk factors for cervical intraepithelial neoplasia: differences between low- and high-grade lesions. American Journal of Epidemiology 140, 700-10.

41. Kjellberg L, Hallmans G, Ahren AM, Johansson R, Bergman F, Wadell G. 2000 Smoking, diet, pregnancy and oral contraceptive use as risk factors for cervical intra-epithelial neoplasia in relation to human papillomavirus infection. British Journal of Cancer 82, 1332-8.

42. Zeegers M, Tan FE, Dorant E, van den Brandt PA. 2000 The impact of characteristics of cigarette smoking on urinary tract cancer risk. Cancer 89, 630639.

43. Anthonisen NR, Skeans MA, Wise RA, Manfreda J, Kanner RE, Connett JE; Lung Health Study Research Group. The effects of a smoking cessation intervention on 14.5- 
year mortality: a randomized clinical trial. Ann Intern Med. 2005;142(4):233-239.

44. Cigarette smoking among adults-United States, 2000. MMWR. 2002:51(29);642-645. http://www.cdc.gov/mmwr/preview/mmwrh $\mathrm{tml} / \mathrm{mm} 5129 \mathrm{a} 3 . \mathrm{htm}$. Accessed December $15,2010$.

45. Fiore MC. US public health service clinical practice guideline: treating tobacco use and dependence. Respir Care. 2000;45(10): $1200-1262$

46. Maugh TH. U.S. smoking rate hasn't changed, CDC says. Los Angeles Times. September $\quad 08, \quad 2010$. http://articles.latimes.com/2010/sep/08/scien ce/la-sci-smoking-20100908. Accessed December 3, 2010.

47. Robert G. Smith (2009) An Appraisal of Potential Drug Interactions in Cigarette Smokers and Alcohol Drinkers. Journal of the American Podiatric Medical Association: January2009, Vol. 99, No. 1, pp. 81-88.

48. Zhou SF, Yang LP, Zhou ZW, Liu YH, Chan E. Insights into the substrate specificity,inhibitors, regulation, and polymorphisms and the clinical impact of human cytochromeP450 1A2. The AAPS journal. 2009 Sep 1;11(3):481-94.

49. Washio I, Maeda M, Sugiura C, Shiga R, Yoshida M, Nonen S, Fujio Y, Azuma J.Cigarette smoke extract induces CYP2B6 through constitutive androstane receptor inhepatocytes. Drug Metabolism and Disposition. 2011 Jan 1;39(1):1-3.

50. Rendic S. Summary of information on human CYP enzymes: human P450 metabolism data. Drug metabolism reviews. 2002 Jan 1;34(1-2):83-448.

51. Schaffer SD, Yoon S, Zadezensky I. A review of smoking cessation: potentially risky effects on prescribed medications. Journal of clinical nursing. 2009 Jun;18(11):1533-40.

52. Tantcheva-Poór I, Zaigler M, Rietbrock S, Fuhr U. Estimation of cytochrome P450CYP1A2 activity in 863 healthy Caucasians using a saliva-based caffeine test.Pharmacogenetics. 1999 Apr;9(2):13144.

53. Lawn S, Pols R. Smoking bans in psychiatric inpatient settings? A review of the research.Australian and New Zealand Journal of Psychiatry. 2005 Jan 1;39(10):866-85.
54. Lucas C, Martin J. Smoking and drug interactions. AustPrescr. 2013 Jun 1;36(3):102-4.

55. Hochholzer W, Trenk D, Mega JL, Morath T, Stratz C, Valina CM, O\&\#39; Donoghue ML,Bernlochner I, Contant CF, Guo J, Sabatine MS. Impact of smoking on antiplatelet effectof clopidogrel and prasugrel after loading dose and on maintenance therapy. American heart journal. 2011 Sep 1;162(3):518-26.

56. de Leon J. Psychopharmacology: atypical antipsychotic dosing: the effect of smoking and caffeine. Psychiatric Services. 2004 May;55(5):491-3.

57. Zevin S, Benowitz NL. Drug interactions with tobacco smoking. Clinical pharmacokinetics. 1999 Jun 1;36(6):425-38.

58. Lyon ER. A review of the effects of nicotine on schizophrenia and antipsychotic medications. Psychiatric Services. 1999 Oct;50(10):1346-50.

59. Gupta V, Tiwari S, Agarwal CG, Shukla P, Chandra H, Sharma P. Effect of short term cigarette smoking on insulin resistance and lipid profile in asymptomatic adults. Indian journal of physiology and pharmacology. 2006;50(3):285.

60. Kroon LA. Drug interactions with smoking. American Journal of Health-System Pharmacy. 2007 Sep 15;64(18):1917-21.

61. Olivier D, Lubman DI, Fraser R. Tobacco smoking within psychiatric inpatient settings: biopsychosocial perspective. Australian \&amp; New Zealand Journal of Psychiatry. 2007Jul;41(7):572-80.

62. Lazarus SC, Chinchilli VM, Rollings NJ, Boushey HA, Cherniack R, Craig TJ, DeykinA, DiMango E, Fish JE, Ford JG, Israel E. Smoking affects response to inhaledcorticosteroids or leukotriene receptor antagonists in asthma. American journal ofrespiratory and critical care medicine. 2007 Apr 15;175(8):783-90.

63. Ito K, Lim S, Caramori G, Chung KF, Barnes PJ, Adcock IM. Cigarette smoking reduces histone deacetylase 2 expression, enhances cytokine expression, and inhibits glucocorticoid actions in alveolar macrophages. The FASEB Journal. 2001Apr;15(6):1110-2.

64. Chalmers GW, Macleod KJ, Little SA, Thomson LJ, McSharry CP, Thomson NC.Influence of cigarette smoking on 
inhaled corticosteroid treatment in mild asthma.Thorax. 2002 Mar 1;57(3):226-30.

65. Cylwik B, Chrostek L, BrodowskaAdamusiak D, Gruszewska E, Daniluk M,Szmitkowski M. The changes of sialic acid concentration and content in apolipoproteinB-containing lipoproteins in the sera of alcoholics. Alcohol and alcoholism. 2010 Jul27;45(5):422-6.

66. Mello NK, Mendelson JH, Sellers ML, Kuehnle JC. Effects of heroin selfadministration on cigarette smoking. Psychopharmacology. 1980 Jan 1;67(1):4552.

67. Chait LD, Griffiths RR. Effects of methadone on human cigarette smoking and subjective ratings. Journal of Pharmacology and Experimental Therapeutics. 1984 Jun 1;229(3):636-40.

68. Zarrindast MR, Faraji N, Rostami P, Sahraei $\mathrm{H}$, Ghoshouni H. Cross-tolerance between morphine-and nicotine-induced conditioned place preference in mice. Pharmacology Biochemistry and Behavior. 2003 Jan 1;74(2):363-9.

69. Vihavainen T, Relander TR, Leiviskä R, Airavaara M, Tuominen RK, Ahtee L,Piepponen TP. Chronic nicotine modifies the effects of morphine on extracellular striataldopamine and ventral tegmental GABA. Journal of neurochemistry. 2008Nov;107(3):844-54
70. Halkin H, Or J, Fuchs Z, Lusky A, Chetrit A, Modan M. Smoking accounts for adverse effect of antihypertensive medications on plasma lipids. A population-based study. Hypertension. 1989 Aug;14(2): 210-7.

71. Kissin B. (1974) Interactions of Ethyl Alcohol and Other Drugs. In: Kissin B., Begleiter H. (eds) The Biology of Alcoholism. Springer, Boston, MA. https://doi.org/10.1007/978-1-4684-29374_4

72. Holder HD. Effects of alcohol, alone and in combination with medications. Walnut Creek(CA): Prevention Research Center. 1992.

73. Lieber CS. Interaction of ethanol with other drugs. In Medical and Nutritional Complications of Alcoholism 1992 (pp. 165-183). Springer, Boston, MA.

74. Koppisetti VS, Chandra N. Influence of Alcohol and Smoking on Drug Action: A Step for better utilization of drugs. J. Chem. 2011;3(1):242-8.

75. Weathermon R, Crabb DW. Alcohol and medication interactions. Alcohol research. 1999;23(1):40.

How to cite this article: Vanjari NK, Sirichandana G, Shaik A et.al. Consequences of the adopted fatal addictive duplet. International Journal of Research and Review. 2021; 8(7): 410-419. DOI: https://doi.org/10.52403/ijrr. 20210759 